\title{
KNOWLEDGE AND ATTITUDE OF STAFF NURSES ON UMBLICAL CORD BLOOD STEM CELL BANKING
}

\author{
Mrs. Ritanjali Sahoo ${ }^{*}$ I Dr. Laxmi Rana ${ }^{* *}$ \\ *Ph. D Scholar, Himalyan University, Itanagar, Arunachal Pradesh, India. \\ ${ }^{* *}$ Research Supervisor, Himalayan University, Itanagar, Arunachal Pradesh, India. \\ DOI: http://doi.org/10.47211/tg.2020.v07iws01.005 \\ Received $14^{\text {th }}$ June 2020, Accepted $20^{\text {th }}$ June 2020, Available online $30^{\text {th }}$ June 2020.
}

\begin{abstract}
:
Umbilical cord blood (UCB) was once considered a waste product and was discarded with the placenta after delivery. With advances in medicine, it has been found to be a rich source of life-saving hematopoietic stem cells and has saved many lives in the recent decades. With advances in cord blood transplantation, many such patients are now able to find a fully or partially HLA-matched cord blood donor. The present study was exploratory descriptive in nature. A total of 170 staff nurses who met the inclusion criteria were selected from City Hospital, Cuttack \& SCB, Medical College \& Hospital, Cuttack, Odisha by using convenient sampling technique. Non experimental descriptive research design was used to conduct the study. Structured interviewing questionnaire was developed by the researchers in English and consisted of three sections on demographic variables, knowledge \& attitude. Tools were reviewed by a panel of five experts to test its content validity. Reliability was done (knowledge $=0.82$ and attitude $=0.78$ ). Pilot study was conducted on 20 nurses. The main study was carried out after getting official permission. The collected data was tabulated and analyzed using descriptive statistics. The study shows that 159 (94\%) had not attended any training on umbilical cord blood stem cell banking. In present study, 55\% staff nurses acquire knowledge on stem cell banking from health professionals. Present study highlighted that nurses' knowledge and attitude regarding umbilical cord blood stem cell banking was inadequate. The study recommends there is need of formal training on cord blood stem cell banking to the staff nurses.
\end{abstract}

KEYWORDS: Knowledge, attitude, staff nurses \& umbilical cord blood stem cells.

\section{ABOUT AUTHORS:}

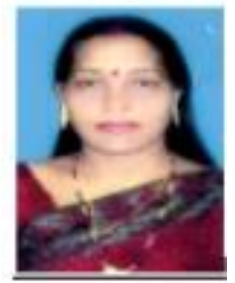

Author Mrs. Ritanjali Sahoo is a Ph. D. Scholar in Himalayan University, Itanagar, Arunachal Pradesh, India.

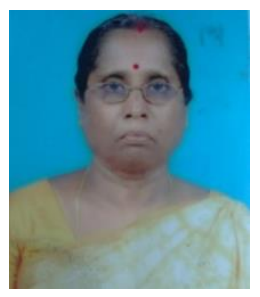

Author Dr. Laxmi Rana (PhD in Nursing) is a Research Guide in Himalayan University, Arunachal Pradesh, India. 


\section{INTRODUCTION:}

Stem cells are the basic units of life are found in all multi cellular organisms; they are repair units of the body that serve a central function in the maintenance and regeneration of organs and tissues throughout an organisms' lifetime. They have the ability to divide for long period of time and can give rise to specialized cells through a process called differentiation and create special types of cells as muscle, nerve, skin, etc. ${ }^{1}$

Umbilical cord blood is rich in stem cells, which are the building blocks of the blood and the immune system. These biologically unique cells have the ability to develop into other cell types within the body. Cord blood as a source of Hematopoietic Stem Cell (HSC) has advantages as it is easily available; involves non-invasive collection procedure and is better tolerated across the human leukocyte antigen barrier. Since the first cord blood transplant in 1988, over 2500 cord blood hematopoietic stem cell transplants have been done worldwide. The proliferative capacity of hematopoietic stem cell in cord blood is superior to that of cell in bone marrow or blood from adults. ${ }^{2}$

Cord blood stem cells can treat over 80 diseases like leukemia, lymphoma, auto immune disorders, brain and spinal cord injuries, autism, hearing loss, cerebral palsy, type 1 diabetes and other dangerous conditions. ${ }^{3}$

The first UCB bank (Umbilical Cord Blood Banks) was stared at the New York blood center in 1992. There are now nearly 142 public banks and at least an additional 25 private banks actively involved around the world in collecting, processing, testing and cryopreserving UCB (Umbilical Cord Blood) for potential future use as therapeutics. There are currently approximately 44 banks over the world and they are connected to the world marrow donor association. There have been over 15,000 cord blood transplants worldwide through $2009 .^{4}$

In India, there are approximately 72000 births daily, which results in discarding 72000 umbilical cords a day. The storage of stem cell rich blood derived from this umbilical cord can prove to be the best possible insurance against life threatening diseases. Indians have high incidence of diseases like Diabetes and Heart ailments, in the treatment of which cord blood can be a godsend, the potential of these stem cells are far higher because they prevent Graft versus Host Disease. ${ }^{5}$

Most UCB banks in India have been opened in the last few years and UCB transplantation is in its infancy, very few reports are available for application to acquired and constitutional hematological disorders. There public banks are established in India Relicord (Mumbai), Jeevan Cord (Chennai) and Stem cyte (Gujrat), collectively having 5,000 units. Similarly, seven private banks have been established to date. These are Cryoviva (Gurgaon), Life cell (Chennai, Gurgaon) with maximum inventory of 19,000 followed by cryo banks having 17,000 plus samples and about 4,500 between Cryo save (Banglore), Cord life (Bangal), Baby cell(Mumbai), stem one and ISSL (international stem cell service) four of these are certified by ISO whereas Lifec cell and Relicordare accredited by AABB. Most of these are affiliated with or are subsidiaries of international companies. ${ }^{6}$

Till date, approximately 32 patients have been transplanted using related or unrelated UCB (umbilical cord blood) of these 2patients of replaced leukemia were transplanted using mismatched sibling cord (UCB processed at life cell and cryo banks) and one died of disease relapse and other of sepsis one child was transplanted using fresh fully matched cord and the child is well 12 years on and a plastic anemia unrelated cord blood was used with TRM of $55 \%$ at Apollo, Chennai. While one patient of leukemia transplanted at Gujarat cancer and research institute (GCRI). ${ }^{7}$.

The major problem faced in India is a collection of UCB (umbilical cord blood) due to high cost and comparatively less functional public banks. In additional, considering the large population with deliveries in public hospitals due to low cost, UCB (umbilical cord blood) storage in India needs increased public private partnership model where UCB (umbilical cord blood) can be stored by affordable and non-affordable people as well.

\section{NEED FOR THE STUDY:}

Umbilical cord blood, which contains a large number of hematopoietic stem cell, has been used successfully for allogeneic transplantation to treat a variety of pediatric genetic, hematologic and oncologic disorders. It is potential alternative when autonomous or allergenic transplantation with Human Leukocyte Antigen matched marrow is unavailable for children.

The umbilical cord was considered medical waste and disposed of following delivery along with placenta due to the lack of knowledge about its benefits and uses. In previous researcher's clinical experiences, they found that there was poor knowledge and negative attitude regarding cord blood and stem cells among maternity nurses. As nurses are the vital health care providers, so it's needful to check knowledge and attitude towards the concept. Hence, it is imperative to raise nurses' knowledge and attitude regarding cord blood collection and its utilization by applying an educational intervention. Studies have shown that cord blood transplants can be performed in cases that have donor and recipient is partially matched. In contrast, bone marrow graft requires full matching in most cases. 
Recent advances in science have demonstrated that umbilical cord blood is a rich source of stem cells, making it valuable tissue resources in the clinical field of stem cell therapy and transplantation. ${ }^{8}$

Nurses are the valuable resource in the process of cord blood collection and stem cell banking, provided they have been equipped with the knowledge and practice to do so. They played a pivot role in performing a variety of functions all over this process, steered from understanding the structure of the umbilical cord to defining the sides of procuring stemcells. ${ }^{9}$

As well, this study recommends the need for in-service educational programs related to stem cells to develop nurses' knowledge, attitudes and practice in order to fit this contemporary trend in health care. Public awareness about umbilical cord blood stem cells banking to correct the myths about stem cell therapy is also a required issue.

\section{METHODOLOGY:}

The study was exploratory descriptive in nature. The main study was conducted A total of 170 staff nurses who met the inclusion criteria were selected from the hospital by using convenient sampling technique.

\section{Research design:}

Non experimental descriptive research design was used to conduct the current study.

Research questions:

1-What are the levels of nurses' knowledge regarding umbilical cord blood stem cells banking?

2-What are the levels of nurses' attitude towards umbilical cord blood stem cells banking?

\section{Setting:}

The study was conducted in City Hospital, Cuttack, Odisha \& SCB Medical College and Hospital, Cuttack, Odisha.

\section{Population:}

The present study population comprised of all nurses who works in both City Hospital, Cuttack, Odisha \& SCB Medical College and Hospital, Cuttack, Odisha.

\section{Sample:}

Convenient sampling technique was used. One hundred seventy (170) nurses in both City Hospital, Cuttack, Odisha \& SCB Medical College and Hospital, Cuttack, Odisha were taken according to the availability and on the basis of inclusion and exclusion criteria to assess knowledge and attitude of nurses regarding umbilical cord blood stem cells banking.

Tools of data collection:

I-Structured interviewing questionnaire was developed by the researchers in English and consisted of three sections:

Section - A: Socio-demographic profile which consists of age, qualification, year of experience \& source of information.

Section - B: Structured knowledge questioners, It consists of a 30 items of multiple choice questions to assess nurses' knowledge regarding umbilical cord blood stem cells banking.

The criterion of Scoring used in the study was extent of score on level of knowledge. Maximum obtainable score was 30 and Nurses' total knowledge score was graded as the following four levels like excellent: (>27), very good: (22-26), good: 18-21, Average: <17. One mark was given for right answer and zero mark given for wrong answer.

Section - C: This tool was developed by the researchers after reviewing related literatures, to assess nurse's attitude towards regarding umbilical cord blood stem cells banking and consisted of (10) items.

The criterion of Scoring: The items were judge according to a three-point Likert scale continuum from favorable (3), neutral (2), and un-favorable (1). Summing up the scores of the items then the overall score gave total attitude score.

Nurse's total attitude score was graded as the following; un-favorable when total score was $(<50 \%)$, neutral when total score was (50-70\%) and favorable when total score was (>71\%).

Validity and reliability of tool:

Tools were reviewed by a panel of five experts in the field of Obstetrics and Gynecological Nursing (3) and Medical Surgical Nursing (2) to test its content validity. Modifications were done accordingly based on their judgment. Reliability was done by Cronbach's Alpha co-efficient test which revealed that the tool consisted of relatively homogenous items as indicated by the moderate to high reliability (internal consistency) of the tool ( nowledge $=0.82$ and attitude $=0.78$ ).

Pilot study:

It was performed on 20 nurses to test the clarity and applicability of the study tool as well as estimation of the time needed to fill the questionnaire. Required modifications were done in the form of adding some questions. Nurses involved in the pilot were excluded from the study. 


\section{ARTICLES}

Data Collection Procedure:

The study was carried out from the beginning of December 2018 to the end of the same month. Official permission was granted. Average time for the completion of each nurse interview was around (10-20 minutes). Limitation of the study:

Insufficient sample size of nurses and shortage of time.

Ethical considerations:

Official permission was granted from the hospital ethical committee. Each nurse who was willing to participate, was received a brief explanation about the purpose and the outcomes of the study and assuring that participation is voluntary with the right to withdraw without any penalty. Furthermore, subjects were assured that all information will be kept confidential by which the researcher only have the right to review.

\section{STATISTICAL ANALYSIS}

The collected data was tabulated and analyzed using descriptive statistics. Frequency and percentage were used to analysis the descriptive data and the knowledge and attitude scores.

Table 1: Frequency \& percentage distribution of nurses by their selected demographic variables $\quad \mathrm{N}=170$

\begin{tabular}{|c|c|c|c|c|}
\hline SI. No. & \multicolumn{2}{|c|}{ Demographic Variables } & Frequency & Percentage \\
\hline \multirow[t]{3}{*}{1.} & \multirow[t]{3}{*}{ Age in years } & $20-25$ & 102 & 60 \\
\hline & & $26-30$ & 57 & 34 \\
\hline & & $31-35$ & 11 & 06 \\
\hline \multirow[t]{3}{*}{2.} & \multirow[t]{3}{*}{ Qualification } & ANM & 10 & 06 \\
\hline & & GNM & 136 & 80 \\
\hline & & B. Sc. Nursing & 24 & 14 \\
\hline \multirow[t]{3}{*}{3.} & \multirow[t]{3}{*}{ Years of Experience } & $1-5$ years & 149 & 88 \\
\hline & & $6-10$ years & 19 & 11 \\
\hline & & $11-15$ years & 02 & 01 \\
\hline \multirow[t]{2}{*}{4.} & \multirow{2}{*}{$\begin{array}{l}\text { Current job } \\
\text { responsibility }\end{array}$} & Staff Nurse & 156 & 92 \\
\hline & & Sister In-charge & 14 & 08 \\
\hline \multirow[t]{2}{*}{5.} & \multirow{2}{*}{$\begin{array}{l}\text { Any additional } \\
\text { information } \\
\text { required? }\end{array}$} & Yes & 104 & 61 \\
\hline & & No & 66 & 39 \\
\hline \multirow[t]{2}{*}{6.} & \multirow{2}{*}{$\begin{array}{l}\text { Have you ever heard } \\
\text { cord blood banking? }\end{array}$} & Yes & 105 & 62 \\
\hline & & No & 65 & 38 \\
\hline \multirow[t]{2}{*}{7.} & \multirow{2}{*}{$\begin{array}{l}\text { Have you ever taken } \\
\text { training on cord } \\
\text { blood banking? }\end{array}$} & Yes & 11 & 06 \\
\hline & & No & 159 & 94 \\
\hline \multirow[t]{2}{*}{8.} & \multirow{2}{*}{$\begin{array}{l}\text { Have you ever } \\
\text { assisted in taking } \\
\text { cord blood } \\
\text { sampling? }\end{array}$} & Yes & 15 & 09 \\
\hline & & No & 155 & 91 \\
\hline
\end{tabular}

Table 2: Frequency \& percentage distribution of nurses in terms of level of knowledge $\quad \mathbf{N}=170$

\begin{tabular}{|c|c|c|}
\hline Level of Knowledge Score & Frequency & Percentage \\
\hline Excellent $(>27)$ & 08 & 18 \\
\hline Very Good (22-26) & 31 & 29 \\
\hline Good (18-21) & 49 & 48 \\
\hline Average (<17) & 82 & \\
\hline
\end{tabular}


Table 3: Frequency \& percentage distribution of nurses' attitude score. $\mathrm{N}=170$

\begin{tabular}{|c|c|c|}
\hline Level of Attitude Score & Frequency & Percentage \\
\hline Unfavourable (<50\%) & 06 & 51 \\
\hline Neutral (50-70\%) & 87 & 45 \\
\hline Favourable (> 71\%) & 77 & (7) \\
\hline
\end{tabular}

Maximum Score-100

Minimum Score-20

Table 4: Range, Mean, Median, Mean\%, Standard deviation of knowledge score of Nurses regarding umbilical cord blood stem cells banking.

\begin{tabular}{|c|c|c|c|}
\hline \multicolumn{2}{|c|}{$\mathbf{N = 1 7 0}$} \\
\hline Variable & Range of Score & Mean & Standard Deviation \\
\hline Knowledge & $04-30$ & 18.25 & 5.74 \\
\hline Attitude & $20-80$ & 55.7 & 9.43 \\
\hline
\end{tabular}

Figure 1: Sources of information on cord blood stem cell banking

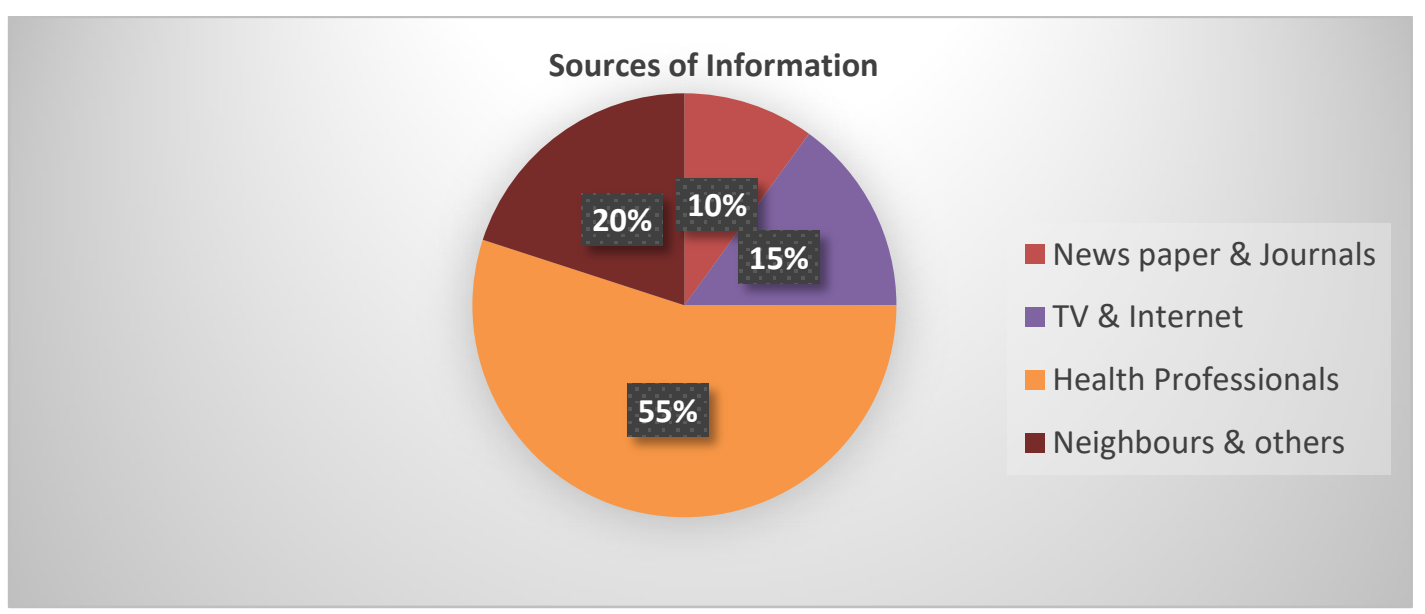

\section{RESULTS:}

Table-1 shows that majority of nurses $102(60 \%)$ were in the age group of $20-25$ years. Majority $136(80 \%)$ had GNM qualifications \& $149(88 \%)$ were within 1-5 years of experiences. Maximum 156(92\%) were staff nurses. Maximum 104 (61\%) were required to know more about cord blood stem cell banking. Maximum159 (94\%) had no formal training on cord blood stem cell banking. Maximum155 (91\%) had not assisted in collection of umbilical cord blood stem cells.

Table-2 shows that majority of nurses 82 (48\%) had average knowledge on umbilical cord blood stem cell banking. 49 (29\%) had good knowledge, 31 (18\%) had very good knowledge and only 8 (5\%) had excellent knowledge on umbilical cord blood stem cell banking.

Table-3 shows that majority of the nurses 87 (51\%) were having neutral attitude, followed by $77(45 \%)$ having favorable attitude and only 6(4\%) nurses had un-favorable attitude towards umbilical cord blood stem cell banking. Table-4 shows that mean knowledge scores of nurses regarding umbilical cord blood stem cells banking was $18.25 \pm 5.74$. The mean attitude scores of nurses regarding umbilical cord blood stem 'cells banking was $55.7 \pm 9.43$.

Figure 1 shows that $55 \%$ staff nurses had acquire knowledge from health professionals on umbilical cord blood stem cell banking, $20 \%$ from neighbors \& others like friends, etc, $15 \%$ from TV \& internet and only $10 \%$ from newspapers \& journals.

DISCUSSION:

Present study highlighted that 159 (94\%) had not attended any training on umbilical cord blood stem cell banking. The findings are constituent with the findings of Mohammed H S and Sayed E I.(2015) ${ }^{12}$ revealed 98.8 $\%(n=52)$ of the maternity nurses had not attended cord blood collection and stem cell training courses.

In present study, 55\% staff nurses acquire knowledge on stem cell banking from health professionals. Similarly, Hatzistilli H \& Zissimopoulou O. (2018) revealed that despite cord blood advances being reported in scientific literature, the main source of information for obstetricians on cord blood banking and use was from private cord blood banks, consistent with findings from midwifery colleagues. Other reported sources of information 
include $\mathrm{n}$ on-scientific magazines, newspapers, university courses, academic papers, seminars and conferences. ${ }^{1}$

Present study highlighted that nurses' knowledge and attitude regarding umbilical cord blood stem cell banking was inadequate. The possible reason for most of the nurses having average knowledge and neural attitude can be attributed to the lack of pre-service and in-service education on umbilical cord blood stem cell banking. The findings are consistent with the finding of Herlihy M M and Delpapa E H. (2013) ${ }^{11}$ on nursing students' reported that their mean knowledge score on hematopoietic stem cell donation was 0.42 (out of 1).Similar findings by Hatzistilli $\mathrm{H}$ et al. $(2018)^{1}$ revealed that among the participated health care workers, only $15.6 \%$ of the subjects were quite well informed on the collection methods and the usage of umbilical cord blood.

In the present study most of the nurses opined that if given a chance, they would like to become resource persons to teach family, friends and general public about public umbilical cord blood banking. This finding is supported by the finding in a study done by Herlihy M M and Delpapa E H. (2013) ${ }^{11}$ who reported that obstetrician and other health care practitioners should have a primary role in efforts to increase the awareness of umbilical cord blood banking.

\section{CONCLUSION:}

The majority of the participants had inadequate knowledge about cord blood stem cells banking and wanted to be informed. Staff nurses preferred formal training to update their knowledge level on umbilical cord blood stem cell banking. The majority of the staff nurses preferred public cord blood banking. Stem cell therapy is emerging as a revolutionary treatment modality to treat diseases and injury, with wide-ranging medical benefits. ${ }^{13}$ The available opportunities to bank stem cells will have the greatest future impact if seized while patients are young and healthy. ${ }^{1}$ The data obtained in this study can also provide a basis for future studies.

\section{REFERENCES:}

1) Hatzistilli H \& Zissimopoulou.O (2018). Health Professionals' knowledge and attitude towards the Umbilical Cord Blood donation in Greece.; 18(2):110-115.

2) Seong-Kyu Park \& Jong-Ho Won. (2009). Usefulness of Umbilical Cord Blood Cells in Era of Hematopoiesis Research.International Journal of Stem Cells; 2(2):90-96.

3) Singh A. K. \& Mc Guirk J P. (2016) Allogeneic stem cell transplantation: a historical and scientific overview. Cancer Research;76(22):6445-6451.

4) Nivethika S.(2018). Umbilical Cord Blood Banking and its Therapeutic Uses. International Journal of Scientific Research and Innovative Technology; 5(1):160-172.

5) Adi Dastur. (2005). Umbilical Cord Blood Banking. The Journal of Obstetrics and Gynecology of India; 55(6):502-504.

6) McKenna D, Sheth J. (2011). Umbilical cord blood: Current status \& promise for the future. The Indian Journal of Medical Research; 134(3):261-269.

7) Prasanna P, Faulkner S, Margaret. (2016). following the banking cycle of umbilical cord blood in India: the disparity between pre banking persuasion and post banking utilization. New Genetics and Society; 35(3):267-288.

8) Farida H. (2017). Evaluation of knowledge and Attitude of Pregnant Saudi Women toward Cord Blood Donation. Journal of Health, Medicine and Nursing; 44:53-63.

9) Indumathi, G Inigo Sherlin J \& Innisaya S,(2018); Effectiveness of Self Instructional Module on Knowledge Regarding Cord Blood Banking Among Staff Nurses at Selected Hospital, Villupuram District IJPCR, June, 2018; 10(6): 162-165.

10) http://www.aicit.org/AISS/ppl/AISS3665PPL.pdf accessed on 17/11/14.

11) Herlihy MM \& Delpapa E H.(2013). Obstetricians and their role in cord blood banking: promoting a public model. Obstetrics and Gynecology;121(4): 851-5.

12) Mohammed H S \& Sayed E I (2015). Knowledge and attitude of maternity nurses regarding cord blood collection and stem cells: An educational intervention. J Nurs Educ Pract.;5(4):58-69.

13) Screnci M, Murgi E, Pirrè G, Valente E, Gesuiti P, Corona F, et al. (2012). Donating umbilical cord blood to a public bank or storing it in a private bank: Knowledge and preference of blood donors and of pregnant women. Blood Transfus ;10:331-7. 